\title{
Semi-automatic grading system in histologic and immunohistochemistry analysis to evaluate in vitro chondrogenesis
}

\author{
María Lucía Gutiérrez, Johana Guevara, Luis Alejandro Barrera* \\ Instituto de Errores Innatos del Metabolismo. Facultad de Ciencias. Pontificia Universidad Javeriana. Bogotá, D.C., Colombia \\ *abarrera@javeriana.edu.co
}

Received: 30-05-2012; Accepted: 05-08-2012

\begin{abstract}
During embryological limb formation mesenchymal cells condense and differentiate into chondrocytes, in a process known as chondrogenesis. These chondrocytes synthesize glycosaminoglycans (GAGs), thus playing an important role in this process. A simplified system in vitro chondrogenesis, using adult mesenchymal stromal cells (MSCs) has been demonstrated. This differentiation potential is usually assessed by histological staining. Objective. Establishment of a semi-automatic grading system for histochemistry stains and immunohistochemistry assays. Materials and methods. For chondrogenesis cells were cultured for three weeks in aggregates with inducing media. Total GAGs were measured using dimethylmethylene blue (DMB) method. For histological analyses aggregates were stained with Alcian blue for total GAGs detection and immunohistochemistry (IHC) for aggrecan was performed. Semi-automatic grading for all slides was obtained after ImageJ analysis. Results. MSCs cultured as aggregates in chondrogenic differentiation media had similar protein concentrations for all time points, suggesting cellularity remained homogenous during culture. Total GAGs was higher for aggregates cultured in chondrogenic compared to complete media. The same trend was observed for Alcian blue stain grades by blinded observer and analysis using ImageJ software. Aggrecan's IHC analysis had a decreasing tendency with time for aggregates in chondrogenic media for blinded observer and ImageJ evaluation. Conclusion. We developed a functional system for semi-automatic slide grading. We corroborated these results by biochemical analysis with comparable results. To our knowledge, for in vitro chondrogenesis, this is the first report to evaluate stains using this methodology. This procedure might be useful for other applications in the field of Biology and Medical Sciences.
\end{abstract}

Key words: mesenchymal stromal cells, in vitro chondrogenesis, glycosaminoglycans, ImageJ

\section{Resumen}

Establecimiento de un sistema de puntaje semi-automático para ensayos histoquímicos e inmunohistoquímicos con el fin de evaluar diferenciación condrogénica in vitro. Durante el desarrollo embriológico las extremidades surgen de la condensación de células mesenquimales y su diferenciación a condrocitos en un proceso llamado condrogénesis. Estos condrocitos sintetizan glicosaminoglicanos, jugando un papel importante durante este proceso. Existe un sistema de condrogénesis in vitro utilizando células mesenquimales generalmente evaluado mediante histoquímica. Objetivo. Establecer un sistema de puntaje semi-automático para ensayos histoquímicos e inmunohistoquímicos. Materiales y métodos. Para condrogénesis las células fueron cultivadas con medio inductor en agregados por tres semanas. Los glicosaminoglicanos totales fueron determinados mediante azul de dimetileno. Para el análisis histológico los agregados fueron teñidos con azul de alcian e inmunohistoquímica para detección de agrecán. La puntuación semi-automática fue obtenida utilizando el programa ImageJ. Resultados. Las células mesenquimales cultivadas en medio de diferenciación condrogénica tuvieron una concentración de proteína comparable durante las tres semanas de cultivo, sugiriendo una celularidad similar. La concentración de glicosaminoglicanos fue superior para los agregados cultivados en medio condrogénico. La misma tendencia fue observada para la tinción de azul de alcian mediante puntajes del observador ciego y análisis con ImageJ. Finalmente, los resultados de inmunohistoquímica de puntajes asignados por el observador y los del análisis por ImageJ revelaron una tendencia decreciente con el tiempo para agregados en medio condrogénico. Conclusión. Desarrollamos un 
sistema funcional para generación de puntaje semi-automático para diferenciación condrogénica. Corroboramos estos resultados mediante anál isis bioquímico con resultados comparables. En nuestro saber este es el primer reporte en evaluar esta metodología, la cual puede ser útil para otras aplicaciones en el campo biológico o médico.

Palabras clave: células mesenquimales, condrogénesis in vitro, glicosaminoglicanos, Imagej.

\section{Resumo}

E stabelecimento de um sistema de pontuação semi-automático para ensaios histoquímicos e imuno-histoquímicos para avaliar diferenciação condrogênica in vitro. D urante o desenvol vimento embrionário os membros emergem a partir da condensação de células mesenquimais e sua diferenciação em condrócitos em um processo chamado condrogênese. Estes condrócitos sintetizam glicosaminoglicanos, desempenhando um papel importante neste processo. Existe um sistema de condrogénese in vitro utilizando cél ulas mesenquimatosas, geralmente avaliado por histoquímica. 0 bjetivo. Estabelecer um sistema de pontuação semi-automático para ensaios histoquímicos e imuno-histoquímicos. Materiais e métodos. $\mathrm{Na}$ condrogênese as células foram cultivadas com meio indutor em agregados, durante três semanas. Os glicosaminoglicanos totais foram determinados pelo azul de dimetileno. Para a análise histológica os agregados foram corados com A zul A lciano e imuno-histoquímica para detecção de agrecan. A pontuação semi-automática foi obtida utilizando o programa Imagej. R esultados. As células mesenquimais cultivadas em meio de diferenciação condrogênica tiveram uma concentração de proteína comparável durante as três semanas de cul tura, o que sugere uma celularidade similar. A concentração de glicosaminoglicanos foi maior para os agregados cultivados em meio condrogênico. A mesma tendência foi observada para a coloração com A zul Alciano segundo as pontuações do observador cego e a análise com I magej. Finalmente, os resultados de imuno-histoquímica de pontuações dados pel o observador e aqueles dados pela análise Imagej revelaram uma tendência decrescente ao longo do tempo para os agregados em meio condrogênico. Conclusão. Nós real izamos um sistema funcional para gerar pontuação semi-automática para diferenciação condrogênica. N ós corroboramos esses resultados por análise bioquímica com resultados comparáveis. Segundo nosso conhecimento, este é o primeiro estudo a avaliar esta metodologia, que pode ser útil para outras aplicações no campo biológico ou médico.

Palavras-chave: células mesenquimais, condrogênese in vitro, glicosaminoglicanos, I mage) .

\section{Introduction}

Chondrogenesis, the first step in endochondral bone formation, is a process where the skeleton is ensued from a cartilage mould or anlagen $(1,2)$. It begins with the recruitment of mesenchymal cells aggregating at the site where future skeletal elements will be formed. Following migration, epithelial-mesenchymal interactions result in condensation (3). M ost bones are formed by this process where mesenchymal cells condense and differentiate into chondrocytes to form a cartilage mould (2). During differentiation mesenchymal cells become chondrocytes and secrete an extracellular matrix (ECM ) rich in aggrecan, a type of proteoglycan composed of a core protein and glycosaminoglycans (GAGs), and collagen type 2 (4). A fter the cartilage mould has been formed, chondrocytes in the center stop proliferating, enlarge and hypertrophy. These modifications are regulated by changes in gene expression, with collagen 10 becoming the principal ECM protein. These hypertrophic chondrocytes direct mineralization of their enveloping matrix and attract blood vessels. L ast, hypertrophic chondrocytes undergo apoptosis to provide the necessary scaffold for true bone matrix deposition with osteoblast and blood vessel invasion (4). These series of highly orchestrated events are characterized by different cellular processes and separate genetic controls (3).
Since chondrogenesis in the embryo is such a complex process for over a decade a simplified system, in vitro chondrogenesis, has been used for studying cellular differentiation using mesenchymal stromal cells (M SCs) (5). M esenchymal stromal cells are multipotent progenitors of connective tissue (6). These cells have the potential to differentiate in vivo or in vitro into mesodermic lineages: adipo-, osteo-, and chondrogenic (7). In addition to their differentiation potential in order to define a MSC two other criteria must be met: M SC s should adhere to plastic and have specific surface antigen expression (8).

Isolated MSCs from human bone marrow cultured in aggregates with defined media containing TG F- $\beta$ appear to promote initial cell density and signaling pathways needed to induce chondrogenic differentiation (9). Furthermore, in vitro chondrogenesis has been demonstrated with MSCs isolated from adipose tissue (10-12). Studies in M SC s isolated from adipose ti ssue have evidenced lower chondrogenic efficiency. However, addition of B M P- 6 has been demonstrated to improve chondrogenic potential (13). A fter the previously mentioned conditions M SCS should undergo chondrogenic differentiation within the following weeks with a characteristic extracellular matrix composed of aggrecan and collagen type 2 (14). Expression of these markers has been used to evidence differentiation. 
In vitro chondrogenic properties have been assessed by biochemical analysis and histological staining (15). M ost reports have eval uated total sul fated GA Gs accumulated in the ECM of aggregates. To this end some have modified a Safranin-0 dye binding assay or dimethylmethylene blue method (16). Chondrogenesis induction of adipose derived M SCs has been confirmed by the presence of sulfated proteoglycans within the matrix by A Ician blue stain, and specific determination of GA Gs by immunohistochemistry (IHC) marker assessment (17).

U sing staining to demonstrate in vitro differentiation into chondrogenic lineage has been an accepted methodology, since it provides evidence for the presence of GA Gs during the chondrogenic process (8). Furthermore, IHC for chondrogenic markers specifically determines the molecule synthesized. $M$ any reports mention that histological assessment was associated with a positive stain in the ECM (10). Others, report a grade based on values given by a blinded observer. It is known that a visual grading system might present an overestimation by the observer. Considering histological analysis is a critical tool to determine in vitro chondrogenesis an objective and quantifiable technique is needed to assess a histological result.

Techniques for quantifying histological stains or IHC markers have been attempted by a number of authors using chromophores and color deconvolution $(18,19)$. We were able to perform an objective and accurate assessment of histochemical stains using color segmentation and IHC marker determination by evaluating hue, saturation and brightness. Hence, in this report we describe how a public domain, Java-based image processing program developed by the $\mathrm{N}$ ational Institutes of Health ImageJ (20), can be used as a semi-automatic grading system for both histochemical stains and IHC marker determination obtained from sections in aggregate cultures during in vitro chondrogenesis.

\section{M aterials and methods}

\section{Mesenchymal stromal cell isolation and culture expansion}

A dipose tissue was collected after informed signed consent from females ( $n=3$ ages: 24 to 38 ) undergoing cosmetic surgery with the approval of the Bioethics Committee at the Pontificia Universidad Javeriana. A dipose tissue MSCs were isolated as previously described with slight modifications (10). B riefly, samples were washed, digested with collagenase (Invitrogen Carlsbad, CA USA) and the stromal vascular fraction (SVF) containing MSC $s$ was resuspended in $\alpha$-M EM (Gibco, Carlsbad, CA) supplemented with $10 \%$ fetal bovine serum (FBS, Eurobio, CEDEX B France), and $100 \mathrm{U} / \mathrm{ml}$ penicillin, $100 \mu \mathrm{g} / \mathrm{ml}$ streptomycin and $0.25 \mu \mathrm{g} / \mathrm{ml} \mathrm{B}$ : amphothericin B (Lonza, Walkerville, M D), hereafter complete media or CM. Cells were seeded and tissue culture plates were incubated at $37{ }^{\circ} \mathrm{C}$ with $5 \%$ $\mathrm{CO}_{2}$ and humidified atmosphere. M edia was changed 24 $\mathrm{h}$ after plating.

\section{M esenchymal stromal cell characterization}

\section{Plastic adherence and I mmunophenotypification}

A dipose derived cells below passage seven were cultured in complete media to evaluate adherence to plastic. Immunophenotypification was determined by MSCS incubation with allophycocyanin (APC), fluorescein isothiocyanate (FITC) and phycoerythrin (PE) conjugated monoclonal antibodies againsthuman CD34 (Dako, Eching Germany), human CD 73 (eB ioscience, San Diego, CA, USA), human CD 90 (FITC Dako, Eching Germany) and human CD 105 (PE, eB iosciences). B ackground fluorescence was established by M SC s incubation with antibodies against IgG 1 (APC and FITC, Dako) and IgGIK for PE (eBioscience). Flow cytometry was performed on a FACSA ria (B ecton Dickson, San Jose, CA ) and results were analyzed using FlowJ o software (Tree Star, A shland OR).

\section{M ultilineage differentiation}

Cells at passage one were trypsinized and $96 \times 10^{3}$ cells were seeded in six well plates and incubated with complete media for $24 \mathrm{~h}$. A dipogenesis and osteogenesis was evaluated culturing cells with media supplemented with inducers according to Zuk et al. (17) with modifications. For adipogenesis we used half the concentration of indomethacin and a 5.8 fold decrease in insulin concentration, and for osteogenesis a fourfold increase in ascorbic acid.

\section{Chondrogenic differentiation}

For chondrogenesis an aggregate culture system was used. B riefly, approximately $250 \times 10^{3}$ cells passage two in CM were placed in a polypropylene tube and centrifuged at 300 $\mathrm{x} g$ for five minutes to form a pellet. Twenty-four hours after centrifugation induction was initiated. The cells were cultured in either complete media or chondrogenic differentiation media (L onza, Walkerville, M D USA) supplemented with B M P-6 (Sigma-A Idrich, St. Louis M O USA) and T GF- $\beta 3$ 
(Invitrogen) at $10 \mathrm{ng} / \mathrm{ml}$ respectively. M edia was changed twice a week for 21 days.

\section{Biochemical analyses}

Total protein was quantified using BCA assay (Pierce,T hermo Scientific Rockford, IL USA ) according to the manufacturer's instructions from aggregate lysate in $0.9 \% \mathrm{NaCl}$ solution. Total sulfated GA Gs (sGAGs) were assayed by spectrophotometric procedure with 1,9-dimethylmethylene blue (Sigma-A ldrich). Total GA G determination by DM B $(\mathrm{mg} / \mathrm{ml})$ was normalized to total protein $(\mathrm{mg} / \mathrm{ml})$.

\section{Histologic and immunohistochemical analysis}

For microscopy analysis, spheres were fixed in $4 \%$ formaldehyde and embedded in paraffin. For total GAG detection $4 \mu \mathrm{m}$ sections were stained with A Ician blue. A ggrecan expression in aggregates was examined by IHC using L eica B iosystem automated B O ND (Leica Biosystems, B uffalo Grove, IL). B riefly, epitope was retrieved for 20 minutes at $\mathrm{pH} 8.8$, followed by primary antibody incubation against aggrecan (Santa Cruz Biotechnology, Santa Cruz, CA) for 15 minutes. Immunolabeling was detected using a B ond Polymer Detection kit (Leica Biosystems) with horseradish peroxidase conjugate and diaminobenzidine (DA B) as substrate.

\section{Image analysis}

Tagged image file format (TIFF) Images were captured by Nikon E600 microscope at 20X magnification (Nikon Corporation, M elville NY, USA), and composite images (magnification) by the robotics microscope at the $\mathrm{B}$ iol ngenium facility at Universidad $\mathrm{N}$ acional de Colombia at $40 \mathrm{X}$. For robotics microscopy image sections were captured and assembled using an algorithm developed by this facility. Histological assessment of A Ician blue stain and IHC marker for aggrecan were performed. For A Ician blue stain the TIFF image was opened with I mage) (Figure 1 A). Then the image was Adjusted to Color Threshold from hue, saturation and brightness (HSB) to red, green, and blue (RGB) color space (Figure $\mathbf{1}$ B black arrow 1). In addition, Threshold color was selected on Red (Figure 1 B black arrow 2). The color threshold was adjusted for each image to depict the areas that display the positive areas of Alcian blue by defining minimum and maximum values for each color (Figure 1 B purple arrows). The mask created by the threshold color was then changed from Red to black and white (B\&W) (Figure 1 C). The Image was changed to grayscale by setting Image Type to 8-bit.
A fter converting the image to grayscale the Image was Adjusted to Threshold into B\& W (Figure 1 D). To define entire aggregate section area $F$ reehand selections delineated the total area (Figure $\mathbf{1} \mathbf{E}$ ). To eliminate pixels outside of selected area Edit Clear Outside was chosen (Figure $\mathbf{1}$ F). To calculate total aggregate section area Analyze was utilized and $M$ easure was chosen (Figure $\mathbf{1}$ F). The value for total section area was recorded. To determine the area of positive A Ician blue stain Analyze followed by Analyze Particles was defined. The value obtained was recorded (F igure 1 G ). To cal culate the area of positive A Ician blue stain the A nalyze particle value was divided by the value recorded for total aggregate section area. The val ue obtained was defined in percentage by multiplying this last result by 100 (Figure $\mathbf{1 ~ H )}$ ). For IHC percentage determination the same procedure aforementioned was utilized with the exception that instead of color segmentation by threshold (RG B) I mage was Adjusted to Color Threshold set in hue, saturation, and brightness (HSB). Since Imagej assessment for both histochemical A Ician blue stain and aggrecan's IHC is a semi-automatic grading system, false positives are not included in the analysis because the person performing the evaluation can omit these areas. To calculate Percentage improvement the following equations were cal culated.

$$
\frac{\text { sem }}{\text { mean }} \times 100=\text { sem percentage }
$$

Where sem is standard error mean for the parameter measured, and mean is the average of the parameter measured. Sem percentage was cal culated for each complete or chondrogenic differentiation media for both blinded observer (BO) or ImageJ (IJ) analysis.

$$
\frac{\text { IJ sem percentage }}{\text { BO sem percentage }}=\text { IJ vs. BO difference }
$$

Where IJ refers to Image standard error mean (sem) percentage as determined in equation (1) and B 0 refers to blinded observer sem percentage as determined in equation (1).

$1-$ IJ vs. BO difference $\times 100$ percentage improvement

Where IJ vs. BO difference were determined in equation (2).

\section{Statistical analysis}

Results are presented as mean \pm standard error mean ( $n=3$ with replicas for each sample). To determine levels of significance results were analyzed using $O$ ne $W$ ay ANOVA followed by Tukey post hoc test. Differences were considered significant at $p<0.05$. Graph Pad Prism Version 3.1 (Graph Pad Software, San Diego Ca, USA) was used for statistical analysis. 

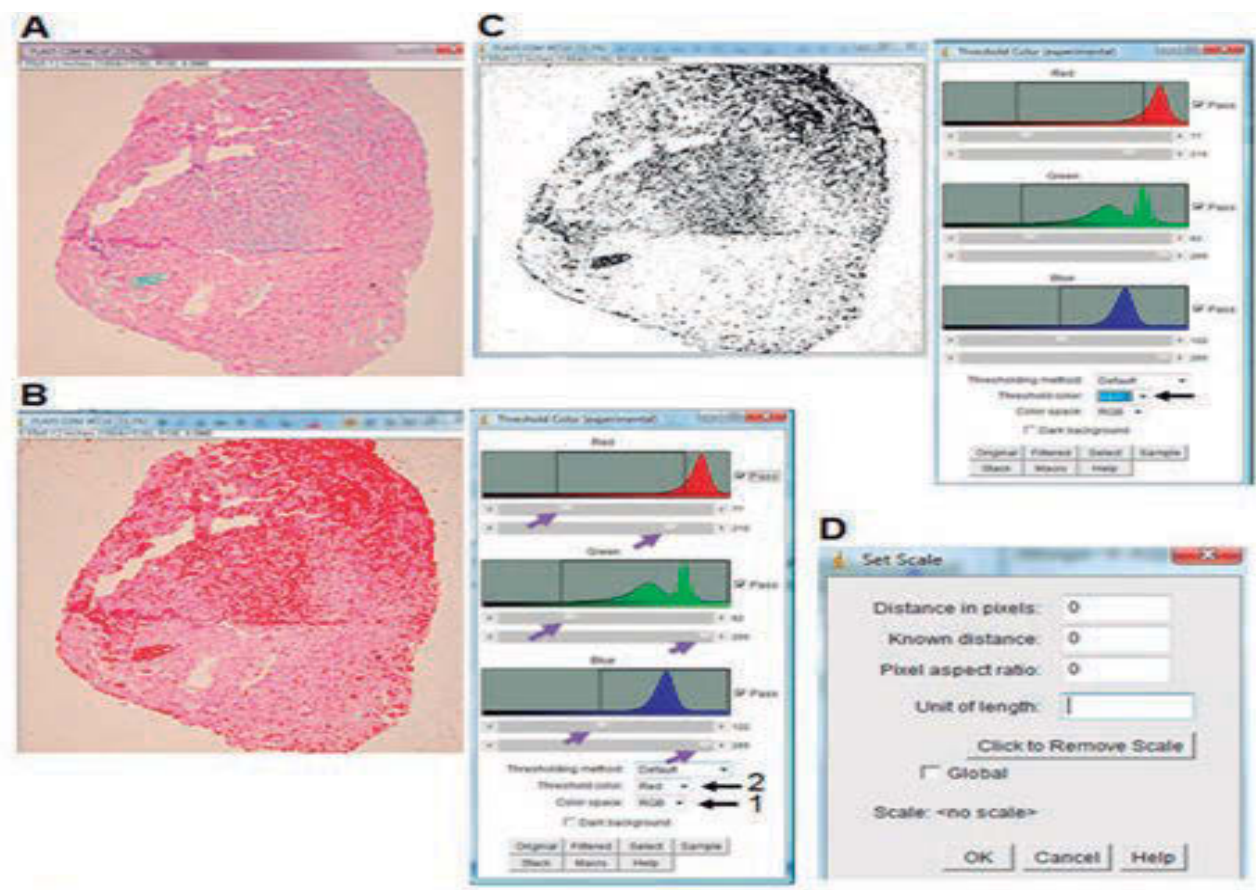

D

E

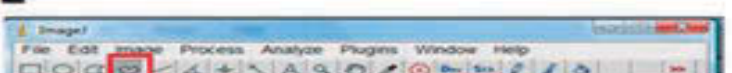

G
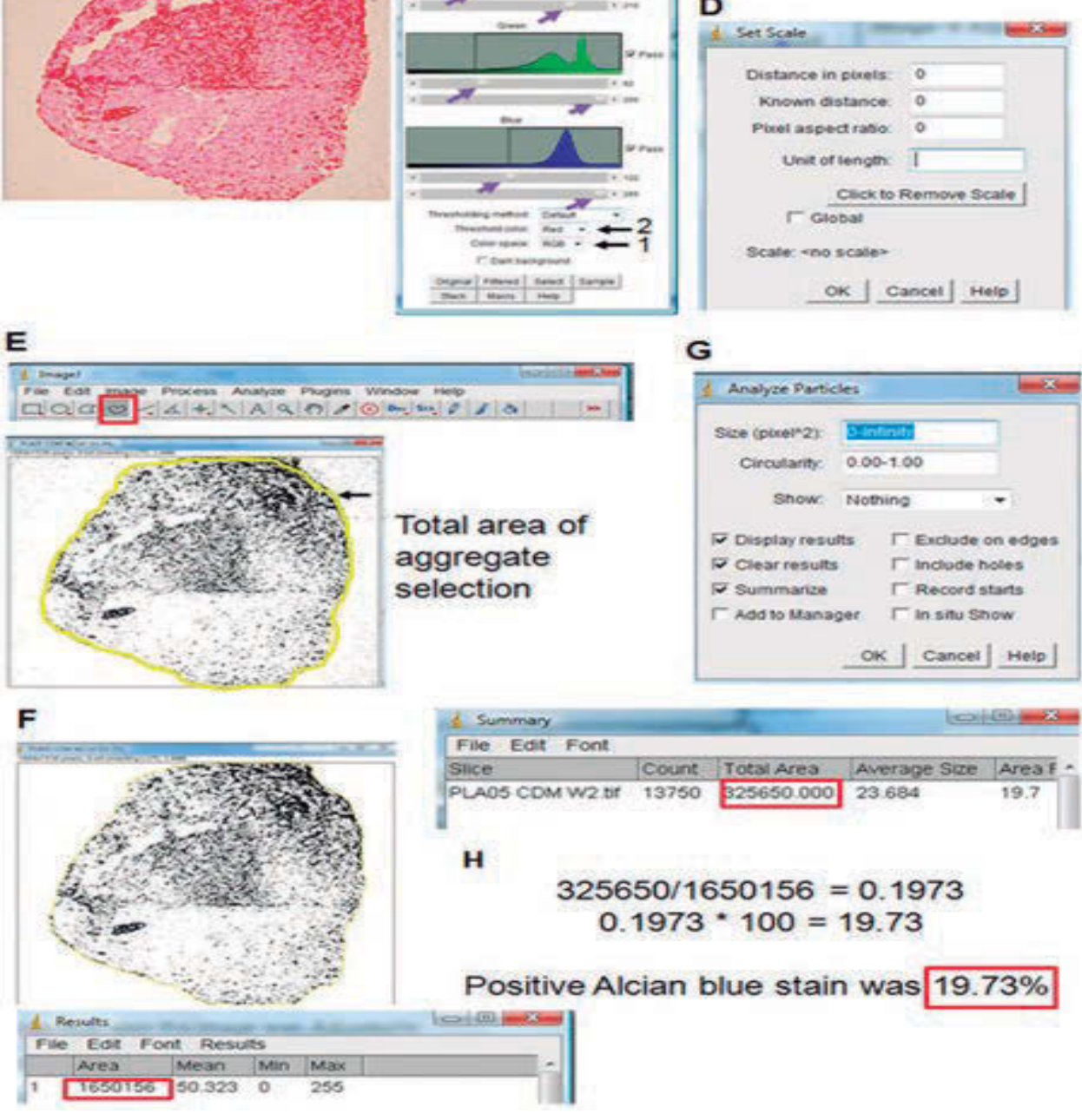

Figure 1. Schematic representation of methodology used for ImageJ analysis. (A) Open Alcian blue image by selecting F ile $\rightarrow 0$ pen Samples $\rightarrow$ PLA 05 CDM W2. (B) A djustment to Red Green and Blue: Image $\rightarrow$ Adjust $\rightarrow$ Color Threshold. In window Color space to RGB (arrow 1) and Color Threshold to Red (arrow 2) were adjusted. Threshold values for each color (purple arrows) were defined. (C) Color Threshold from Red to $B \& W$ (arrow) was changed. Threshold Color window was closed. (D) Color image was converted to grayscale: I mage $\rightarrow$ Type $\rightarrow$ 8-bit. I mage $\rightarrow$ Adjust $\rightarrow$ Threshold $\rightarrow$ BW $\rightarrow$ apply. Analyze $\rightarrow$ Set scale. V alues were selected as depicted. $\mathbf{O K}$ was selected. (F) To eliminate background noise $\mathbf{E}$ dit $\rightarrow \mathbf{C l e a r}$ outside was elected. To measure pixel number in selected area Analyze $\rightarrow$ M easure was chosen. (G) Positive Alcian blue area was determined by Analyze $\rightarrow$ Analyze particle. V alue was recorded. (H) Percentage positive area was calculated by dividing: $325650 / 1650156=0.1973$. This obtained value was multiplied by 100 to obtain percentage $0.1973 \times 100=19.73$. Positive A lcian blue stain was $19.73 \%$. 


\section{Results}

A dipose tissue derived cells were adherent to plastic and met all the characteristics as previously described in the literature for M SCs (8). They were positive for CD 73, CD90, and CD 105 and less than $2 \%$ of the population assayed was positive for CD 34 (Figure2 A and B). Cells differentiated into adipogenic, osteogenic and chondrogenic lineages as determined by positive stain for each lineage (Figure 2 D, F and 8 B, D).

Protein concentration for aggregate cultures in chondrogenic differentiation media was comparable $(0.05 \pm 0.01 \mathrm{mg} /$ $\mathrm{ml}$ ) for all three weeks (Figure 3), with a non-significant protein concentration decrease for the third week of culture (A N OV A $p>0.05$ ). Protein within aggregates cultured in
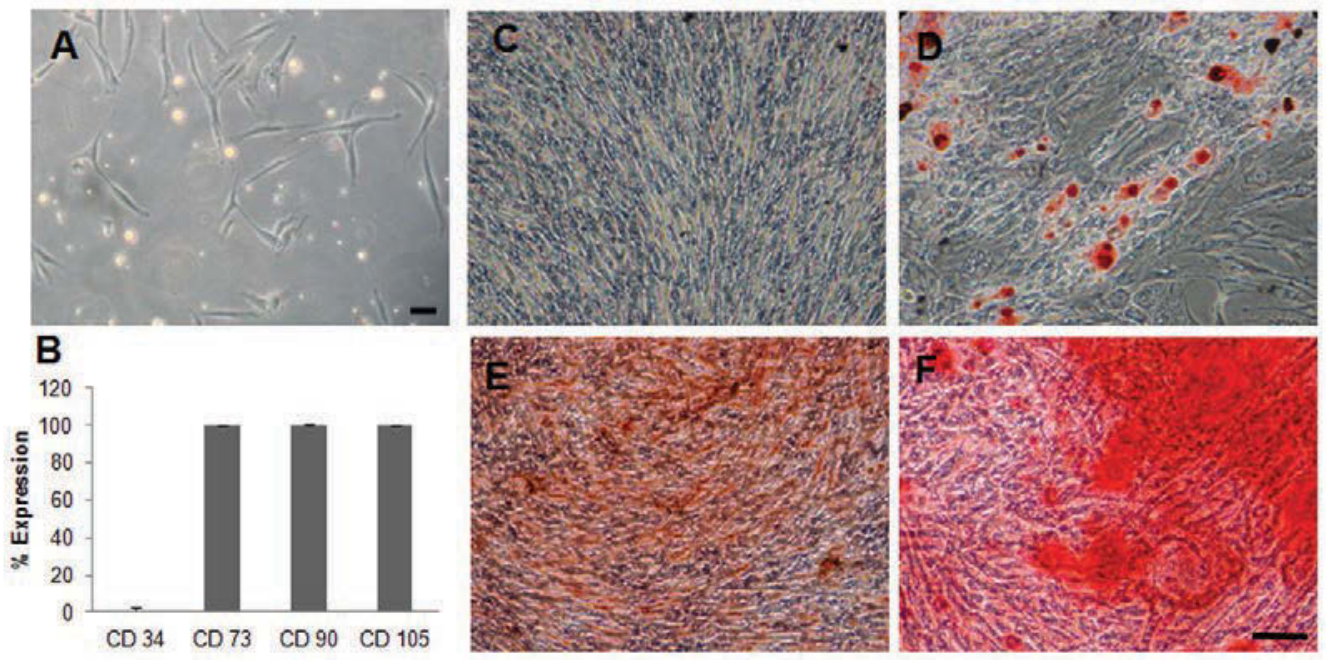

Figure 2. M SC identification criteria. (A) M SC morphology isolated from processed lipoaspirate. Fibroblast-like cells adherent to plastic at passage one. Scale bar $200 \mu \mathrm{m}, 10 \mathrm{X}$ magnification. (B) Immunophenotypic profile of adipose derived M SCs. Cells were incubated with antibodies against human CD 34, CD 73, CD 90 and CD 105 with respective isotype control $(n=3)$. Adipogenic differentiation. (C) Representative sample of cells cultured in complete media. (D) Staining of neutral fat lipid droplets to confirm adipogenesis was detected by Oil Red 0 stain for cells cultured in media with inducers. 0 steogenic differentiation. (E) Cells cultured in complete media. (F) Extracellular calcium deposits were determined by A lizarin Red stain in cells cultured in complete media with inducers. Scale bar $100 \mu \mathrm{m}$. C - F photographs at 20X magnification.

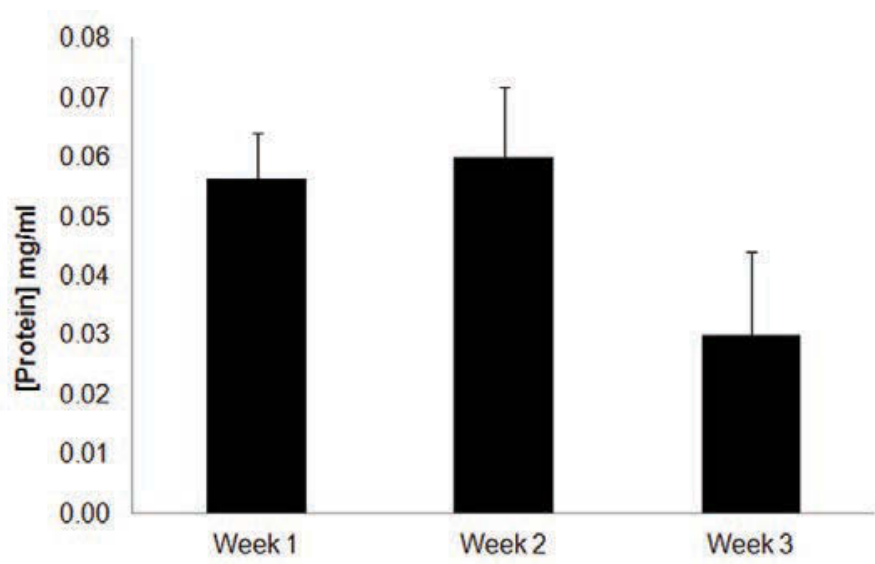

Figure 3. Aggregate total protein quantity. Bicinchoninic acid protein (BCA) quantity of cell lysate reported in $\mathrm{mg} / \mathrm{ml}$ for $250 \times 10^{3}$ cell aggregate formed at day zero by centrifugation and cultured in chondrogenic differentiation media during one, two or three weeks. Values are the mean \pm sem. A NOV A $p>0.05$ 
CM was not detected for all three weeks of culture. For all three time points (week 1, week 2, and week 3) total GA Gs were higher for aggregates cultured in chondrogenic differentiation media compared to M SCs in CM (Figure 4 A). Furthermore, DM B results normalized to total protein had the same trend as total GA G concentration for aggregates cultured in chondrogenic differentiation media (Figure 4 B). Normalization of DMB results to total protein could not be performed for aggregates cultured in $\mathrm{CM}$, given that total protein was not detected.

Since total protein values for aggregates cultured in $\mathrm{CM}$ were undetected we proceeded to analyze total GAGs to compare aggregates cultured in CM vs. chondrogenic differentiation media by microscopy histological analysis of A lcian blue based on two blinded observers with a grading
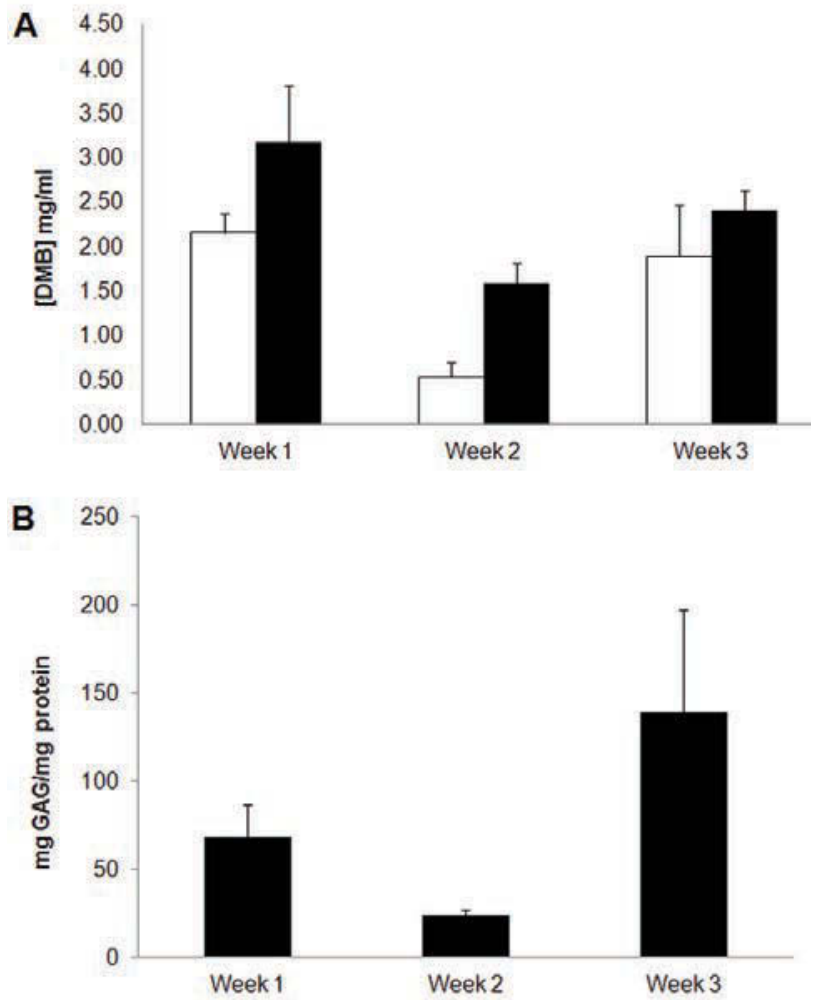

Figure 4. Total sG AG. Biochemical composition of M SC aggregates on days 7, 14, and 21 of culture. Total GAG content was measured with dimethylmethylene blue method (DMB). (A) White bars represent aggregates cultured in complete media (CM). B lack bars represent aggregates cultured in chondrogenic differentiation media. No significant differences were observed between media during three weeks of culture (B) DM B values $(\mathrm{mg} / \mathrm{ml})$ normalized to total protein $(\mathrm{mg} / \mathrm{ml})$ for aggregates cultured in chondrogenic differentiation media. One way A NOV A $p>0.05$. system from zero (no stain) to three. Positive A lcian blue evidenced a significant higher grade for all aggregates cultured in chondrogenic differentiation media compared to aggregates cul tured in CM for the same time points (A N OV A $p<0.05$ ), suggesting chondrogenic differentiation (Figure 5). In addition these results had a comparable trend to that observed for total GAGs determined by DM B, and DM B normalized to protein. Furthermore, A I cian blue stain based on percentage of positive stain determined by Image analysis also evidenced a significant higher percentage of positive area for aggregates in chondrogenic differentiation media compared to sections from aggregates cultured in $\mathrm{CM}$ during all three time points (A N OV A p < 0.05), again confirming chondrogenic differentiation. The trend for total GAGs determined by A Ician blue percentage anal yzed by I mage] for aggregates cultured in chondrogenic differentiation media was different from that obtained by DM B and DM B normalized to total protein. A Ician blue percentage decreased with time with a gradual diminishment from $19.50 \pm 1.15$ to $8.77 \pm 1.13$. A dditionally, highly significant differences were also observed among aggregates in chondrogenic differentiation media between the first and second week compared to the third week of culture (Figure 6).

Last, IHC evaluations using either blinded grading or ImageJ percentage analysis were similar for aggregates under chondrogenic differentiation media. For both types of analysis i.e blinded observer and I mage), a non significant decreasing tendency with time for aggrecan's IHC marker assessment was observed. Furthermore, ImageJ IHC analysis had an analogous tendency compared to that of A Ician blue percentage also determined by ImageJ. The opposite effect was observed for aggregates in CM with an increase in IHC marker determination for both methodologies (Figure 7).

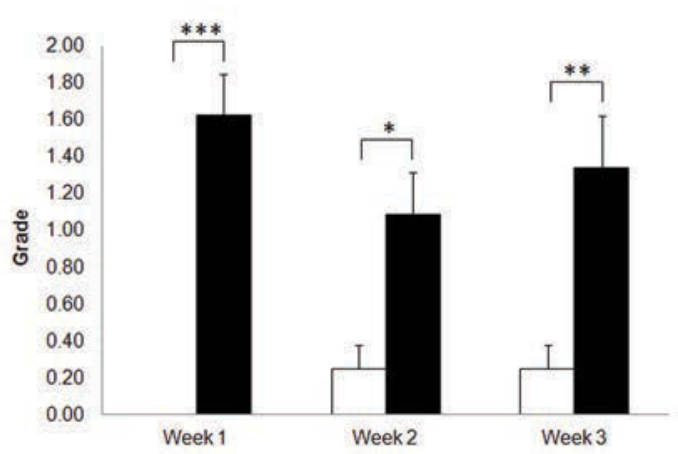

Figure 5. A Ician blue blinded observer score. Cells cultured in aggregates in CM (white bars) or chondrogenic differentiation media (black bars) during first, second and third week of culture. Stain was qualified based on a grading system from zero to three ( $0=$ no stain). O ne way A N OV A $* p<0.05, * * p<0.01, * * * p<0.001$. 


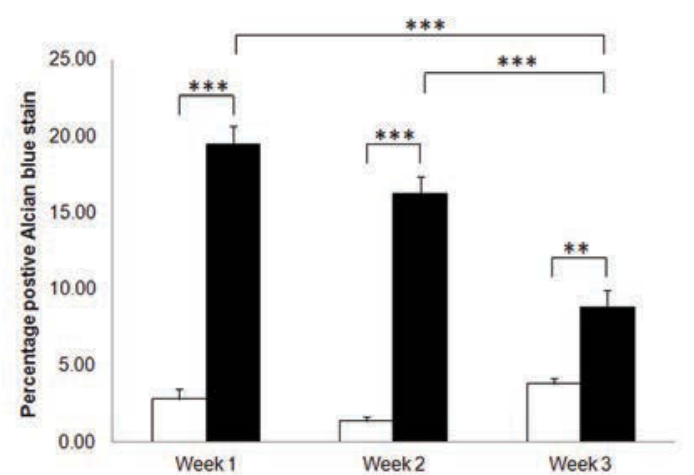

Figure 6. Alcian blue positive stain percentage using Imagej. Cells cultured in aggregates in CM (white bars) or chondrogenic differentiation media (black bars) during first, second and third week of culture. Percentage was determined as described in detail in $M$ aterials and $M$ ethods section. One way ANOVA ** $p<0.01, * * * p<0.001$.

When comparing aggrecan's IHC results between blinded observer grade and ImageJ percentage a starker contrast between CM and chondrogenic differentiation media was observed for the ImageJ analysis. No significant differences were observed for blinded observer or Imagej analysis.
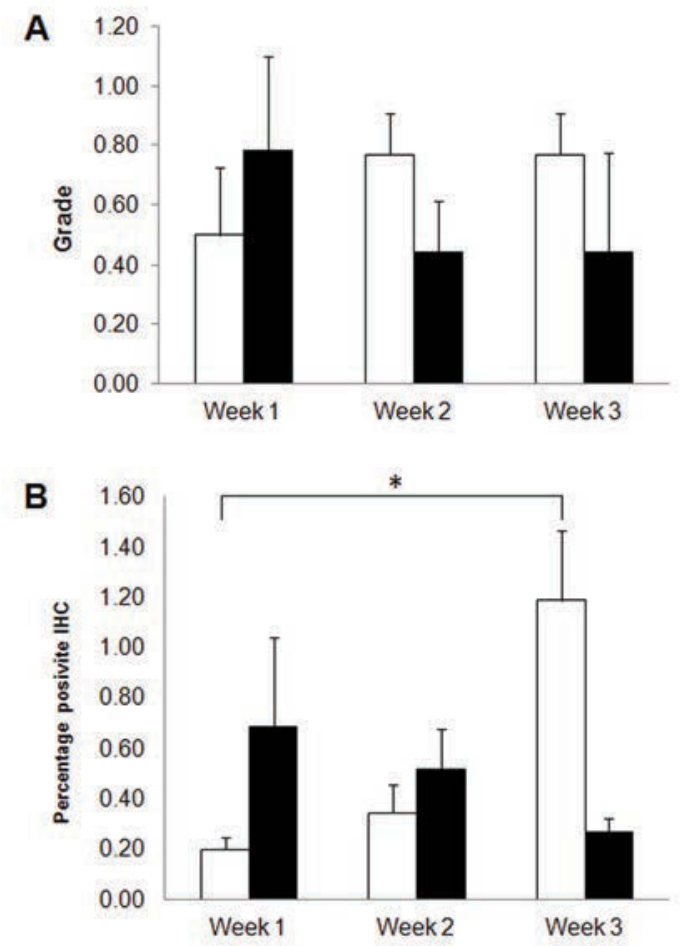

Figure 7. Aggrecan IHC score. IHC aggrecan marker in M SCs cultured in complete (white bars) or chondrogenic differentiation media (black bars) during three week aggregate culture. (A) Blinded observer grade. One way ANOVA $p>$ 0.05 . (B) I mageJ percentage. One way A N OVA $* p<0.05$.

\section{Discussion}

We devel oped a functional system for semi-automatic slide grading for M SCs in vitro chondrogenic differentiation using ImageJ, a public domain, Java-based image processing program developed by the $\mathrm{N}$ ational Institutes of $\mathrm{H}$ ealth in 1997 (20). This open-source software permits cuttingedge image processing and can be used as an indispensible support for researchers in different fiel ds. To our knowledge this methodology innovates in the way histological slides are eval uated for in vitro chondrogenic determination. We corroborated image analysis results by biochemical analysis with comparable results. For histochemical procedures color segmentation was applied, with color filter values selected by the evaluator. Furthermore, we devel oped a novel IHC quantification technique not relying on color segmentation based on RGB intensities, but rather on hue saturation and brightness (HSB). Consequently, this procedure could be used for other applications in the biological and medical fields depending on the user's need.

Chondrogenesis was activated by a commercial available media supplemented with IG F-1, insul in, transferrin, TGF- $\beta 1$ TGF- $\beta 3$ and B M P-6, all are known chondrogenic inducers (21-23). Chondrogenic differentiation was confirmed by A Ician blue stain by blinded observer eval uation and Image] percentage determination. Spheroids cultured for three weeks in CM had a lower grade (blinded observer) or lower percentage (I mage) ) compared to aggregates in chondrogenic differentiation media. Thus, confirming that inducers had an effect on total GA G synthesis during aggregate culture, and suggest cells in chondrogenic differentiation media were undergoing chondrogenic differentiation process.

For A Ician blue stains in aggregates cultured in complete or chondrogenic differentiation media we calculated the percentage difference in standard error mean (sem) between Imagej and conventional blinded observer methodology (Table 1). Results obtained using Image) software demonstrated a greater than $50 \%$ improvement in relation to conventional blinded observer methodology. These results suggest that error can be substantial ly reduced when using a more objective methodology for image analysis and scoring.

Our results obtained by histological analysis were supported by biochemical assays that proved aggregates cultured in chondrogenic differentiation media had a higher GA G concentration in their ECM compared to those cultured in $C M$. These results agree with those previously reported in the literature (17). Furthermore, DM B results for CM could not be normalized to total protein, because of undetectable protein values. These results evidence the 
Table 1. Alcian blue Percentage Improvement.

A ggregates cultured in complete or chondrogenic differentiation media were assayed at days 7, 14 or 21 for either media. Improvement analysis referred to as percentage improvement was calculated as described in materials and methods section. IJ: Image). B O: B linded observer. N.D. Not determined.

\begin{tabular}{ccc}
\hline & Alcian blue & \\
\hline Media & $\begin{array}{c}\text { Time of } \\
\text { culture } \\
\text { (days) }\end{array}$ & $\begin{array}{c}\text { IJ vs. BO } \\
\text { percentage } \\
\text { improvement }\end{array}$ \\
\hline Complete & 7 & $\mathrm{~N} . \mathrm{D}$ \\
media & 14 & $53.38 \%$ \\
\hline Chondrogenic & 21 & $79.34 \%$ \\
Differentiation & 7 & $56.87 \%$ \\
media & 14 & $68.25 \%$ \\
\hline
\end{tabular}

limitations of biochemical assays for very small samples. Since chondrogenic differentiation characteristics based on biochemical criteria presented an obstacle (undetectable protein for aggregates in CM) we developed this semiautomatic functional system using Imagej to perform a more objective and accurate assessment of histochemical stains and IHC marker to determine in vitro chondrogenesis.

For biochemical assays we used DM B method as described by Farndale with modifications (24). This highly sensitive technique permitted to assay total GA Gs concentration from $5 \mu \mathrm{g} / \mathrm{ml}$ to $50 \mu \mathrm{g} / \mathrm{ml}$ from a sample with low protein quantities, as those obtained in this work from a lysed aggregate with a range of protein content from $0.03 \pm 0.01$ $\mathrm{mg} / \mathrm{ml}$ to $0.060 \pm 0.01 \mathrm{mg} / \mathrm{ml}$. We observed total protein did not have a significant change throughout the chondrogenic process. This suggests cel lul arity remained similar during the three weeks when aggregates were cul tured in chondrogenic differentiation media.

M oreover, we normalized total GA Gs to total protein. U sing total protein to normalize total GA Gs provides advantages such as cost reduction and a less cumbersome methodology compared to other parameters such as total DNA $(9,25)$. On the other hand, this technique is not sensitive enough to quantify very low protein values. This could explain why we were unable to detect protein for $\mathrm{CM}$, and could not normalize DM B results for aggregates cultured in CM.

For aggrecan's IHC we observed ImageJ methodology had a better performance for aggregates cultured in chondrogenic media compared to MSCs cultured in CM (Table 2). A gain, as for the A Ician blue stain this technique presents greater advantages as compared to conventional grading methodologies.

\section{Table 2. Aggrecan I HC Percentage I mprovement.}

A ggregates cultured in complete or chondrogenic differentiation media were assayed at days 7, 14 or 21 for either media. Improvement analysis referred to as percentage improvement was calculated as described in the materials and methods section. If : Image) . B O: B linded observer.

\begin{tabular}{ccc}
\hline & \multicolumn{2}{c}{ Aggrecan IHC } \\
\hline Media & $\begin{array}{c}\text { Time of } \\
\text { culture } \\
\text { (days) }\end{array}$ & $\begin{array}{c}\text { IJ vs. BO percentage } \\
\text { improvement }\end{array}$ \\
\hline Complete & 7 & $43.39 \%$ \\
media & 14 & No improvement \\
\hline Chondrogenic & 21 & No improvement \\
Differentiation & 14 & No improvement \\
media & 21 & $18.31 \%$ \\
\hline
\end{tabular}

Even though the objective of this study was to establish a semi-automatic grading system; contrasting results betw een total GA Gs and aggrecan detection by IHC are important for their biological implications. A ggrecan is composed of two types of GA Gs, a small keratan sulfate domain and a larger chondroitin sulfate domain (26). We observed a gradual aggrecan decrease with time for aggregates cultured in chondrogenic differentiation media in contrast to GA G/ protein biochemical analysis with an increase for the last week of culture. A ggrecan is not the only GA G synthesized during chondrogenesis (27). Other GA Gs, such as heparan sulfate, dermatan sulfate and syndecan, could be involved in the process, probably explaining these contrasting results.

During the earlier stages of chondrogenesis mesenchymal cells differentiate into chondrocytes and begin to synthesize collagen type 2 and aggrecan. This event sets the stage for mesenchymal cell differentiation into chondrogenesis (28). In a report of human adipose $\mathrm{M} \mathrm{SC}$ s undergoing chondrogenic differentiation aggrecan expression was restricted to early events, days seven and ten, and was specific to aggregates under chondrogenic induction (17). Other studies with human adipose derived M SCs al so have demonstrated aggrecan's expression after seven days of culture in chodrogenic differentiation media (11, 22). A ggrecan synthesis initiates during chondroprogenitor proliferation and differentiation and its synthesis stops with terminal differentiation (1). Thus, 
our blinded observer and Image] percentage analysis results for aggregates cultured in chondrogenic media agree with reports in the literature regarding aggrecan's expression. These results demonstrate the biological importance of computer assisted quantification of histological results during in vitro chondrogenesis that corroborate with biochemical and immunological attributes to determine differentiation.

For histological analysis images were captured by conventional microscopy. This technique permitted to obtain for most slides the entire section at 20X magnification with low resolution. A thigher magnification (40X) images have higher resolution, but the section cannot be captured completely. In order to provide a solution we used robotic microscopy. We compared at random captured images from conventional microscopy and robotic microscopy and observed an improvement with the latter. A comparison between both microscopy capture methodologies for A Ician blue stain is depicted in Figure 8. On panel A, B, and C we observe images captured by robotics microscopy. As can be seen, robotics captured images appear as if part of the background were missing. This is the result of the assembling process, since each section is captured, according to the algorithm designed, and the assembled image does not guarantee an image with a homogenous background. The robotics image capture provides the researcher several advantages over images captured with a conventional microscope. For one, it allowed greater detail, since the complete section can be integrated as one image. In contrast, conventional microscopy, as that observed by panel $D$ does not permit this type of detail. In order to capture the entire aggregate section the objective must be at 20X. For larger slide sections using conventional microscopy capture techniques, for example those a pathologist might encounter, integration of images would have to be carried out manually. Collectively, robotics microscopy improves detail, because it integrates the complete section at 40X magnification with aid of an algorithm developed by $\mathrm{Biol}$ ngenium engineers. This complete image can then be analyzed by I mageJ .

Panels $C$ and $D$ in figure 8 demonstrate Image analysis percentage determination. The area that was positive for A lcian blue stain is highlighted in red. This is more easily observed for panel $D$, where the aggregate was cultured in chondrogenic differentiation media. This methodology permits more objectivity compared to blinded observer
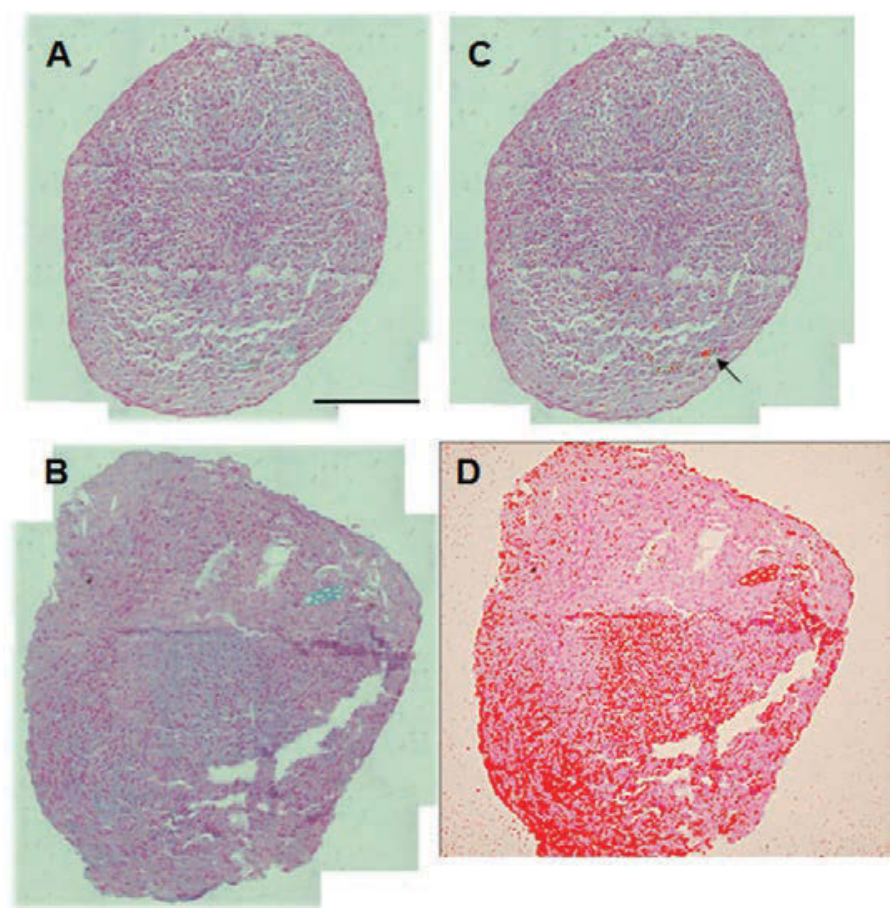

Figure 8. A lcian blue stain analysis using Image . A ggregates cultured in complete (A and C) or chondrogenic differentiation media (B and $\mathbf{D}$ ) for 14 days. (A) A ggregate section of representative sample during two weeks of culture in complete media. Digitally photographed at high resolution $(40 X)$ by automated system. Captures were assembled into one image by algorithm designed by Biolngenium. Scale bar $100 \mu \mathrm{m}$. (B). Representative sample of aggregate cultured in chondrogenic differentiation media. (C) Color segmentation to determine threshold values for capture in A. (D) Color segmentation to determine threshold values for capture in B. 
evaluation, because the observer by using ImageJ can quantify in a semi-automatic manner the slide section and give a percentage of positive stain or IHC chondrogenic marker to determine differentiation.

A lthough techniques for quantifying histological stains have been reported $(18,19,29)$, recent devel opment in automated image analysis describe the use of sophisticated digital capture of histological slides. This type of equipment cost can range from $\$ 100,000$ to $\$ 300,000$ US dollars. Furthermore, IHC analysis requires use of DAB deconvolution to digitally separate different stains, and some researchers describe using methods implementing ImageJ macro (18). Other image processing programs offer an image processing toolbox that can be used for color space conversion and image filtering, such as MATLAB, yet this software must be purchased. In this report we present an option for capturing images at high resolution and analyzing them using free software.

\section{Conclusion}

W e devel oped a functional system for semi-automatic slide grading, and corroborated these results by biochemical analysis with comparable results for in vitro chondrogenesis. This computer assisted quantification provided a percentage improvement compared to blinded observer methodology. To our knowledge this is the first report to evaluate stains using this methodology providing a quantifiable and impartial technique to assess in vitro differentiation. In addition, automated image analysis enables improved detail and accuracy for slide assessment. This methodology represents an advantage for the researcher analyzing and scoring slide sections. Overall, these findings suggest that semi-automatic grading system using ImageJ is a more objective way to analyze microscopy images and can be applied to other fields.

\section{Acknowledgement}

We would like to thank Felipe A maya for providing lipoaspirate samples. We are grateful to the Pontificia Universidad J averiana flow cytometry core laboratory for their hel p with flow cytometry analyses, in particular Sandra Quijano. We thank Engineers M aria Cristina Lasso and A ngel Cruz for assistance with robotic image capturing, algorithm design for image assembly, and Image analysis method development at the Biolngenium Core Facility at Universidad Nacional de Colombia, B ogotá.

\section{F inancial Support}

This work was funded by Colciencias Grant 1203440820438.

\section{Conflicts of Interest}

The authors indicate no potential conflicts of interest.

\section{R eferences}

1. Goldring M B, Tsuchimochi K, Ijiri K. The control of chondrogenesis, J ournal of Cellular Biochemistry 2006; 97 (1): 33-44.

2. K arsenty G, K ronenberg HM, Settembre C. Genetic control of bone formation, Annual Review of Cell and D evelopmental Biology 2009; 25: 629-648.

3. Hall BK, Miyake T. All for one and one for all: condensations and the initiation of skeletal development, BioE ssays 2000; 22 (2): 138-147.

4. K ronenberg HM. Developmental regulation of the growth plate, Nature 2003; 423 (6937): 332-336.

5. J ohnstone B, H ering TM , Caplan A I, Goldberg V M , Y oo JU. In vitro chondrogenesis of bone marrow-derived mesenchymal progenitor cells, Experimental Cell Research 1998; 238 (1): 265-272.

6. Y oo JU, Barthel TS, Nishimura K, Solchaga L, Caplan A I, Goldberg V M, J ohnstone B. The chondrogenic potential of human bone-marrow-derived mesenchymal progenitor cells, The J ournal of Bone and J oint Surgery. American volume 1998; 80 (12): 1745-1757.

7. Baksh D, Song L, Tuan RS. A dult mesenchymal stem cells: characterization, differentiation, and application in cell and gene therapy, J ournal of Cellular and M olecular M edicine 2004; 8 (3): 301-316.

8. Dominici M, Le Blanc K, M ueller I, Slaper-Cortenbach $I, M$ arini $F, K$ rause $D, D$ eans $R, K$ eating $A$, Prockop $D$, Horwitz $E$. M inimal criteria for defining multipotent mesenchymal stromal cells. The International Society for Cellular Therapy position statement, Cytotherapy 2006; 8 (4): 315-317.

9. M urdoch A D, Grady L M , A blett M P, K atopodi T, M eadows RS, Hardingham TE. Chondrogenic differentiation of human bone marrow stem cells in transwell cultures: generation of scaffold-free cartilage, Stem Cells 2007; 25 (11): 2786-2796.

10. Zuk PA, Zhu M, M izuno H, Huang J, Futrell J W, K atz AJ, B enhaim $P$, L orenz HP, Hedrick M H. M ultilineage cells from human adipose tissue: implications for cell-based therapies, Tissue Engineering 2001; 7 (2): 211-228.

11. Erickson GR, Gimble J M, Franklin DM , Rice HE, A wad $H$, Guilak F. Chondrogenic potential of adipose tissue- 
derived stromal cells in vitro and in vivo, Biochemical and Biophysical Research Communications 2002; 290 (2): 763-769.

12. Winter $A, B$ reit $S, P$ arsch $D, B$ enz $K$, Steck $E, H$ auner $H$, W eber RM , E werbeck V, Richter W. Cartilage-like gene expression in differentiated human stem cell spheroids: a comparison of bone marrow-derived and adipose tissuederived stromal cells, Arthritis and Rheumatism 2003; 48 (2): 418-429.

13. Hennig T, Lorenz H, Thiel A, Goetzke K, Dickhut A, Geiger $F$, Richter W. Reduced chondrogenic potential of adipose tissue derived stromal cells correlates with an altered T G F beta receptor and B M P profile and is overcome by B M P-6, J ournal of C ellular P hysiology 2007; 211 (3): 682-691.

14. Solchaga LA, Penick KJ, Welter JF. Chondrogenic differentiation of bone marrow-derived mesenchymal stem cells: tips and tricks, M ethods in M olecular Biology 2011; 698: 253-278.

15. Ghone N V , Grayson WL. Recapitulation of mesenchymal condensation enhances in vitro chondrogenesis of human mesenchymal stem cells, J ournal of C ellular P hysiology 2012.

16. Mueller M B, Tuan RS. Functional characterization of hypertrophy in chondrogenesis of human mesenchymal stem cells, Arthritis and Rheumatism 2008; 58 (5): 13771388.

17. Zuk PA, Zhu M, A shjian P, De Ugarte DA, Huang JI, $\mathrm{M}$ izuno $\mathrm{H}$, A lfonso $\mathrm{ZC}$, Fraser JK, B enhaim $\mathrm{P}$, Hedrick $\mathrm{MH}$. Human adipose tissue is a source of multipotent stem cells, M olecular Biology of the Cell 2002; 13 (12): 4279-4295.

18. Helps SC, Thornton E, K leinig TJ, M anavis J, V ink $R$. A utomatic nonsubjective estimation of antigen content visualized by immunohistochemistry using color deconvolution, Applied Immunohistochemistry \& Molecular M orphology 2012; 20 (1): 82-90.

19. K rajewska M , Smith L H, Rong J, Huang X, Hyer M L, Zeps $\mathrm{N}$, lacopetta B, Linke SP, OIson A H, Reed J C, K rajewski S. Image analysis algorithms for immunohistochemical assessment of cell death events and fibrosis in tissue sections, The J ournal of $\mathrm{H}$ istochemistry and Cytochemistry 2009; 57 (7): 649-663.
20. Collins TJ. Image for microscopy, Biotechniques 2007; 43 (1 Suppl): 25-30.

21. Bohme K, Conscience-Egli M, Tschan T, Winterhalter $\mathrm{KH}, \mathrm{B}$ ruckner $\mathrm{P}$. Induction of proliferation or hypertrophy of chondrocytes in serum-free culture: the role of insulinlike growth factor-I, insulin, or thyroxine, The J ournal of Cell Biology 1992; 116 (4): 1035-1042.

22. Estes BT, Wu AW, Guilak F. Potent induction of chondrocytic differentiation of human adipose-derived adult stem cells by bone morphogenetic protein 6 , Arthritis and Rheumatism 2006; 54 (4): 1222-1232.

23. Rich JT, Rosova I, Nolta JA, Myckatyn TM, Sandell LJ, M CA linden A. U pregulation of Runx2 and Osterix during in vitro chondrogenesis of human adipose-derived stromal cells, Biochemical and Biophysical Research Communications 2008; 372 (1): 230-235.

24. Farndale RW, Sayers CA, Barrett AJ. A direct spectrophotometric microassay for sulfated glycosaminoglycans in cartilage cultures, Connective Tissue Research 1982; 9 (4): 247-248.

25. Penick KJ, Solchaga LA, W elter JF. High-throughput aggregate culture system to assess the chondrogenic potential of mesenchymal stem cells, Biotechniques 2005; 39 (5): 687-691.

26. Rodriguez E, Roland SK, Plaas A, Roughley PJ. The glycosaminoglycan attachment regions of human aggrecan, The J ournal of Biological Chemistry 2006; 281 (27): 18444-18450.

27. DeLise AM, Fischer L, Tuan RS. Cellular interactions and signaling in cartilage development, 0 steoarthritis and Cartilage 2000; 8 (5): 309-334.

28. Blair HC, Zaidi M , Schlesinger PH. M echanisms balancing skeletal matrix synthesis and degradation, The B iochemical J ournal 2002; 364 (Pt 2): 329-341.

29. Leal S, Diniz C, Sa C, Goncalves J, Soares A S, RochaPereira C, Fresco P. Semiautomated computer-assisted image analysis to quantify 3,3'-diaminobenzidine tetrahydrochloride-immunostained small tissues, Analytical Biochemistry 2006; 357 (1): 137-143. 